10. Гук А. Органи господарських товариств $з$ одним учасником. Юридичний журнал. 2006. № 8. С. 98-103.

11. Крупка Ю. М., Міщук В. В. Особливості правового статусу товариства з одним учасником. Науковий часопис НПУ імені М. П. Драгоманова. Серія 18. Економіка і право. 2014. № 25. С. 183-190.

12. Про затвердження модельного статуту товариства з обмеженою відповідальністю: Постанова Кабінету Міністрів України від 16 листопада 2011 р. № 1182. Офіційний вісник України. 2011. № 90. Ст. 3268. (Із змінами).

DOI 10.31558/2518-7953.2018.1-2.13

УДК 346.7:656.615 (477)

В. М. Панасюк

аспірант Донецького національного університету імені Василя Стуса

\title{
ПРАВОВА ОСНОВА ГОСПОДАРСЬКОЇ ДІЯЛЬНОСТІ У ЗБРОЙНИХ СИЛАХ УКРАЇНИ
}

Ключові слова: Збройні Сили Украӥни, господарська діяльність, землі оборони, військове майно.

Збройні Сили України являють собою військове формування, на яке покладається оборона України, захист ії територіальної цілісності та недоторканності. 3 метою одержання додаткових джерел фінансування життєдіяльності військ (сил) для підтримання на належному рівні їх бойової та мобілізаційної готовності у Збройних Силах України здійснюється господарська діяльність, для чого важливе значення має ії правова основа.

Правову основу господарської діяльності у Збройних Силах України складають закони України «Про Збройні Сили України» [1], «Про господарську діяльність у Збройних Силах України» [2], «Про використання земель оборони» [3], «Про правовий режим майна у Збройних Силах України» [4], Положення про військове (корабельне) господарство Збройних Сил України, затверджене наказом Міністерства оборони України [5], і інші нормативно-правові акти. У рамках сформованого законодавства визначено поняття та загальні засади господарської діяльності у Збройних Силах України, правовий режим військового майна (у тому числі порядок його відчуження та надання в оренду), земель оборони, ведення підсобного господарства. Разом з тим зазначені нормативно-правові акти не позбавлені прогалин і інших недоліків, що потребують усунення. 
У юридичній науці загальні питання правових засад господарської діяльності досліджував В. К. Мамутов [6]. Правові питання щодо господарювання у Збройних Силах України опрацьовували П. М. Кондик [7], О. Р. Зельдіна [8], Е. Г. Бойченко [9]. Над окремими аспектами правових засад господарської діяльності у Збройних Силах працював В. Й. Кісель [10]. Однак, низка питань щодо правових засад зазначеної діяльності залишаються дискусійними та потребують теоретичного опрацювання.

Наведене вказує на актуальність обраної теми, метою дослідження якої $\epsilon$ обгрунтування пропозицій щзодо удосконалення правової основи господарської діяльності у Збройних Силах Украӥни.

Загальні правові засади господарської діяльності визначені Господарським кодексом України. У ньому наведено загальне визначення господарської діяльності (ст. 3), закріплено основні положення щодо видів такої діяльності (глава 29), iï суб'єктів (ст. 55), майнової основи господарювання (ст. 67; розділ III), господарських зобов'язань (розділ IV) та ін. Зазначені положення цього Кодексу стосуються і господарської діяльності у Збройних Силах України.

Крім зазначеного, Господарським кодексом України окремо закріплено можливість здійснення у Збройних Силах України лише господарської некомерційної діяльності та можливість врегулювання відносин, пов'язаних із здійсненням такої діяльності іншими законами; надано визначення господарської діяльності у Збройних Силах України (ст. 414) [11].

Базовим законом, положення якого є складовою правової основи господарської діяльності у Збройних Силах України, є Закон України «Про Збройні Сили України». У ньому закріплено загальне визначення Збройних Сил України, можливість здійснення господарської діяльності у Збройних Силах України, та при цьому передбачено звільнення від сплати усіх видів податків за користування закріпленими за військовими частинами, військовими навчальними закладами, установами, організаціями Збройних Сил України землями, водами, іншими природними ресурсами, а також майном відповідно до законів з питань оподаткування. 3 наведеного слідує, що питання звільнення від сплати податків таких суб’єктів господарювання має бути врегульовано на рівні податкового законодавства.

Законом, який регулює відносини у сфері оподаткування, в тому числі і стосовно господарської діяльності у Збройних Силах України, є Податковий кодекс України [12]. У ньому визначено види податків, порядок їх адміністрування, коло платників податків та зборів, їх права та обов’язки, а також відповідальність за порушення податкового законодавства. Крім того, закріплено спеціальні податкові режими, у рамках яких можливо встановити особливий, пільговий порядок оподаткування або взагалі передбачити звільнення від сплати окремих подат- 
ків і зборів, проте для суб'єктів господарювання Збройних Сил України цим Кодексом жодних пільг не передбачено.

На це звертає увагу Верховний Суд України, який у постанові від 29 січня 2013 р. у справі № 21-431a12 зробив висновок про відсутність підстав для звільнення від оподаткування суб'єктів господарювання Збройних Сил України у зв’язку з відсутністю у спеціальній нормі (Податковому кодексі України) відповідних пільг [13]. Як наслідок норма Закону про звільнення Збройних Сил України від сплати усіх видів податків не знаходить свого подальшого відображення у Податковому кодексі України. На актуальність законодавчого встановлення пільг податкового характеру для спеціальних режимів господарювання звертав увагу В. К. Мамутов ще у 2001 році [8 с. 13], з ним пізніше, у 2015 році, погодився Е. Г. Бойченко [9, с. 113], проте питання оподаткування господарської діяльності у Збройних Силах України потребує подальшого опрацювання.

Наступним законом, що складає правову основу зазначеної діяльності, є Закон України «Про правовий режим майна у Збройних Силах України». В ньому закріплено визначення військового майна, повноваження органів військового управління та посадових осіб, які здійснюють управління цим майном, особливості правового режиму військового майна, порядок обліку, інвентаризації, списання, відчуження та утилізації військового майна. Разом з тим є підстави стверджувати, що визначений Законом перелік видів військового майна (ст. 1) є неповним, оскільки у цьому переліку не зазначаються земельні ділянки, які згідно зі ст. 181 Цивільного кодексу України віднесено до нерухомих речей [14].

До правової основи господарської діяльності у Збройних Силах України належать також відповідні положення Земельного кодексу України. Стосовно правового режиму земель, які використовуються для потреб Збройних Сил України, Кодексом закріплено, зокрема, визначення земель оборони, передбачено їх перебування виключно у державній чи комунальній власності, створення навколо військових об'єктів захисних, охоронних та інших зон з особливими умовами користування, особливості відчуження таких земель. Крім того, Земельним кодексом України передбачено, що порядок використання земель оборони встановлюється окремим законом.

Таким законом є Закон України «Про використання земель оборони». У ньому дублюється закріплене у Земельному кодексі України визначення земель оборони, встановлено право військових частин на отримання земельних ділянок у постійне користування, передбачено, що особливості надання земельних ділянок під військові об'єкти згідно з Законом визначаються Кабінетом Міністрів України, проте наразі останнім вони не визначені. Крім того, Законом передбачено право власників сусідніх ділянок на встановлення сервітутів, встановлено особливий режим використання земель навколо військових частин та визначено за- 
ходи охорони навколишнього природного середовища та екологічної безпеки на землях оборони.

Особливе місце у цьому Законі відведено питанням використання земель оборони в господарських цілях (ст. 4). Законом закріплено право військових частин за погодженням 3 органами місцевого самоврядування або місцевими органами виконавчої влади дозволяти фізичним і юридичним особам вирощувати сільськогосподарські культури, випасати худобу та заготовляти сіно на землях, наданих їм у постійне користування. Згідно з ч. 1 ст. 4 Закону такий дозвіл має надаватися в порядку, визначеному Кабінетом Міністрів України, проте на сьогоднішній день Кабінет Міністрів України цей порядок не визначив.

Натомість зазначені питання частково врегульовано наказом Міністра оборони України від 22 грудня 1997 р. № 483 «Про затвердження Положення про порядок надання в користування земель (земельних ділянок) для потреб Збройних Сил України та основні правила користування наданими землями». Положенням детально визначено процедуру отримання у користування земель, до якої входить погодження місць розташування, оформлення клопотань про відведення землі, отримання рішення відповідних Рад, розробка проектів відведення земельних ділянок, виготовлення документів. Крім цього, у Положенні передбачено здійснення обліку наданих земельних ділянок; контроль за використанням і охороною земель; порядок вирішення (врегулювання) земельних спорів, отримання державних актів, освоєння земельних ділянок безпосередніми землекористувачами; можливість передачі земель оборони у користування для сінокосіння та випасання скоту, посіву сільськогосподарських культур; можливість передачі земель місцевим органам влади [15].

Поряд із зазначеним ст. 4 Закону України «Про використання земель оборони» передбачає можливість використовувати землі оборони для будівництва об'єктів соціально-культурного призначення, житла для військовослужбовців та членів їх сімей, а також соціального та доступного житла без зміни їх цільового призначення. Також у статті врегульовано питання відчуження земельних ділянок, на яких розташовані об'єкти нерухомого військового майна, що підлягають реалізації, та земельних ділянок, які вивільняються у процесі реформування Збройних Сил України, Державної спеціальної служби транспорту.

На виконання вищеназваної статті Закону постановою Кабінету Міністрів України від 22 травня 2013 р. № 436 затверджено Порядок відчуження земельних ділянок, на яких розташовані об'єкти нерухомого військового майна, що підлягають реалізації, та земельних ділянок, які вивільняються у процесі реформування Збройних Сил і Державної спеціальної служби транспорту [16]. У Порядку врегульовано процедуру складання переліків земельних ділянок, які можуть бути відчужені разом з розташованими на них об'єктами нерухомого військового 
майна, та переліків земельних ділянок, які вивільняються у процесі реформування Збройних Сил і Держспецтрансслужби та підлягають реалізації. Встановлено форми для кожного переліку та порядок їх затвердження Кабінетом Міністрів України, визначено строк дії такого затвердженого переліку (п'ять років), процедуру проведення земельних торгів, оцінки вартості земельної ділянки, укладення договору з організатором земельних торгів, погодження проекту землеустрою відведеної земельної ділянки, розміщення оголошення про проведення земельних торгів, зазначено інформацію, яка повинна міститися у цьому оголошенні, суб’єктний склад учасників торгів (не можуть бути учасниками торгів іноземні держави, іноземні юридичні особи та іноземці), вимоги щодо оголошення стартової ціни, порядок подання заяви на участь у земельних торгах та проведення земельних торгів, ведення протоколу та його підписання, оформлення результатів продажу лота, укладення договору купівлі-продажу, його нотаріального посвідчення та державної реєстрації, оприлюднення результатів та порядок внесення коштів, підписання двохстороннього акту звірки взаєморозрахунків.

3 наведеного слідує, що питання використання земель оборони певною мірою врегульовано. Проте можна погодитись з А. М. Мірошниченком та Р. І. Марусенком, які стверджують, що Закон України «Про використання земель оборони» хоча і прийнятий, але майже не має регулятивного значення, оскільки $\epsilon$ механічним відтворенням положень статті 77 Земельного кодексу України та викладенням бланкетних норм, що в свою чергу вказує на потребу подальшого його доопрацювання [17].

Основним законом, який регулює господарську діяльність Збройних Сил України є Закон України «Про господарську діяльність у Збройних Силах України». У ньому наведено визначення господарської діяльності у Збройних Силах України (яке повністю ідентичне з тим, що міститься у Господарському кодексі України) та визначено суб'єкти і види такої діяльності; порядок реєстрації військових частин як суб’єктів господарської діяльності, їх відповідальність; вказано на можливість обмеження та припинення господарської діяльності військової частини; особливості передачі в оренду рухомого та нерухомого майна Збройних Сил України, порядок обліку та використання коштів, одержаних від господарської діяльності Збройних Сил України. При цьому у Законі «Про господарську діяльність у Збройних Силах України» відсутнє визначення та порядок ведення підсобного господарства, яке згадується у ст. 1 цього Закону та ст. 414 Господарського кодексу України.

В свою чергу вказане питання на відомчому рівні врегульовано наказом Міністерства оборони України від 16 липня 1997 р. № 300 «Про затвердження Положення про військове (корабельне) господарство Збройних Сил України». А саме, це Положення визначає основи організації та ведення військового (кора- 
бельного) господарства загалом; права та обов'язки посадових осіб військової частини (корабля) та з'єднання, пов'язані з веденням військового (корабельного) господарства; порядок планування та здійснення контролю господарської діяльності; порядок організації матеріально-технічного, аеродромно-технічного, ветеринарного, торговельно-побутового, квартирно-експлуатаційного, фінансового та іншого забезпечення; порядок приймання і здачі посади та облікової документації особами, на яких покладено ведення військового (корабельного) господарства; порядок створення військового господарства при формуванні та порядок ліквідації його при розформуванні військової частини (з'єднання).

Крім того, Законом України «Про господарську діяльність у Збройних Силах України» передбачено, що Кабінетом Міністрів України за поданням Міноборони, узгодженим з центральним органом виконавчої влади з питань економічної політики, затверджуються види військового майна, яке не підлягає приватизації. В свою чергу на рівні Кабінету Міністрів України чи на відомчому рівні такі види не затверджені.

Також Законом закріплено, що Кабінетом Міністрів України визначається перелік видів господарської діяльності, здійснення якої дозволяється військовим частинам. На виконання цієї норми постановою Кабінету Міністрів України від 25 липня 2000 р. № 1171 [18] затверджено відповідний перелік, який містить 126 видів господарської діяльності.

Згідно з вимогами вказаного Закону постановою Кабінету Міністрів України від 3 травня 2000 р. № 749 затверджено й Порядок реєстрації військових частин як суб'єктів господарської діяльності у Збройних Силах. Такий Порядок містить визначення суб'єктів господарювання Збройних Сил, які підлягають реєстрації, зразок подання для реєстрації військової частини як суб'єкта господарювання, перелік документів, які до нього додаються, зразок реєстраційної картки військової частини як суб'єкта господарської діяльності. Крім цього, Порядком встановлено десятиденний строк, виділений Міністерству оборони України для проведення реєстрації або відмови у реєстрації військової частини, визначено зразок свідоцтва про реєстрацію, необхідність повідомлення податкових органів та органів Державного казначейства про таку реєстрацію, підстави для відмови у реєстрації військової частини, припинення господарської діяльності військової частини за рішенням Міноборони, порядок та підстави проведення перереєстрації військової частини та порядок внесення змін у свідоцтво про реєстрацію військової частини як суб'єкта господарської діяльності у Збройних Силах [19].

Статтею 7 Закону України «Про господарську діяльність у Збройних Силах України» передбачено, що Кабінетом Міністрів України визначається порядок надання дозволу військовим частинам на передачу закріпленого за ними рухомого та нерухомого військового майна в оренду. Такий Порядок затверджено поста- 
новою Кабінету Міністрів України від 11 травня 2000 р. № 778 [20]. У Порядку дублюється надане Законом України «Про правовий режим майна у Збройних Силах України» визначення військового майна та встановлено особливості отримання дозволу для передачі в оренду рухомого і нерухомого військового майна, визначено процедуру отримання такого дозволу.

Також Законом України «Про господарську діяльність у Збройних Силах України» передбачено, що порядок обліку та використання коштів, одержаних від господарської діяльності у Збройних Силах України, визначається Міністерством фінансів України та Міністерством оборони України. Відповідно, наказом Міністерства оборони України від 3 серпня 2016 р. № 400 «Про затвердження Положення про облік та використання коштів спеціального фонду державного бюджету в Міністерстві оборони України» врегульовано порядок розподілу коштів, отриманих як плата за послуги, між бюджетними установами та Міністерством оборони України. Зокрема, йдеться про розподіл коштів, отриманих від основної та додаткової (господарської) діяльності, від оренди майна, від реалізації майна, від сплати житлово-комунальних послуг (діяльність гуртожитків, готелів, комендантських дільниць, засобів тимчасового розміщення і проживання тощо), від благодійних внесків.

Вищевказаними нормативно-правовими актами досі не врегульованим залишається питання матеріальних стимулів особового складу військових частин, задіяного у господарській діяльності Збройних Сил України, на що свого часу звернув увагу Е. Г. Бойченко та запропонував шляхи вирішення зазначеної проблеми [9, с. 207], з якими можна погодитись.

Таким чином, проведений аналіз вказує на наявність у правовій основі господарської діяльності у Збройних Силах Украӥни недоліків, які полягають у тому, що деякі підзаконні нормативно-правові акти, на які містяться посилання у законах, досі не прийнято, а окремі чинні нормативно-правові акти потребують конкретизації.

Для удосконалення правової основи господарської діяльності у Збройних Силах України пропонується:

у частині 2 статті 14 Закону Украӥни «Про Збройні Сили Украӥни» виключити слова «та звільняються від сплати усіх видів податків відповідно до законів з питань оподаткування»; натомість норму про сприятливий режим оподаткування суб 'єктів господарювання Збройних Сил Украӥни закріпити у Законі України «Про господарську діяльність у Збройних Силах України», виділивщи під неї окрему статтю, в якій серед іншого зазначити, щьо такий режим визначається податковим законодавством України;

у Податковому кодексі України пункт 282.1 статті 282 (де передбачено пільги для сплати земельного податку юридичним особами) доповнити підпунк- 
том 282.1.7, зазначивши серед кола суб'єктів, які звільняються від сплати такого податку, суб 'єктів господарювання Збройних Сил України;

y статті 1 Закону Украӥни «Про правовий режим майна у Збройних Силах Украӥни» включити до переліку видів військового майна також земельні ділянки.

Подальші наукові дослідження правової основи господарської діяльності у Збройних Силах України доцільно присвятити конкретизації положень щодо сприятливого режиму оподаткування у податковому законодавстві, правового режиму використання земель оборони та інших, на які зверталась увага в вищенаведеному аналізі.

1. Про Збройні Сили України: Закон України від 6 грудня 1991 р. № 1934-XII. Вiдомості Верховної Ради України. 2000. № 48. Ст. 410. (Із змінами).

2. Про господарську діяльність у Збройних Силах України: Закон України від 21 вересня 1999 р. № 1076-ХIV. Відомості Верховної Ради Украӥни. 1999. № 48. Ст. 408. (Із змінами).

3. Про використання земель оборони. Закон України від 27 листопада 2003 р. № 1345-IV. Відомості Верховної Ради України. 2004. № 14. Ст. 209. (Із змінами).

4. Про правовий режим майна у Збройних Силах України: Закон України від 21 вересня 1999 р. № 1075-XIV. Відомості Верховної Ради Украӥни. 1999. № 48. Ст. 407. (Із змінами).

5. Про затвердження Положення про військове (корабельне) господарство Збройних Сил України: Наказ Міністерства оборони України від 16 липня 1997 р. № 300. Офіційний вісник Украӥни. 1997. № 52. Ст. 202. (Із змінами).

6. Мамутов В. К. Развитие хозяйственного законодательства и хозяйственно-правовой мысли в суверенной Украине: науч. докл. Ин-т экономико-правовых исслед. НАН Украины. Донецк, 2004. 40 с.

7. Кондик П. М. Правові аспекти визначення статусу військового майна. Вісник господарського судочинства. 2002. № 3. С. 161-165.

8. Мамутов В. К., Зельдина Е. Р. Развитие законодательства о специальном режиме хозяйствования. Предпринимательство, хозяйство и право. 2001. № 1. С. 9-12.

9. Бойченко Е. Г. Правове регулювання господарської діяльності військових частин Збройних Сил України: дис. ...канд. юрид. наук: 12.00.04. Одеса, 2015. 241 с.

10. Кісель В. Й. Поняття та правовий режим військового майна: цивільно-правовий аспект. Юридична Україна. 2006. № 2. С. 59-63.

11. Господарський кодекс України: Закон України від 16 січня 2003 р. № 436-IV. Вiдомості Верховної Ради Украӥни. 2003. № 18, № 19-20, № 21-22. Ст. 144. (Із змінами).

12. Податковий кодекс України: Закон України від 2 лютого 2010 р. № 2755-VI. Відомості Верховної Ради України. 2011. № № 13-17. Ст. 112.

13. Постанова Верховного Суду України від 29 січня 2013 р. у справі № 21-431а12. Сдuний державний реєстр судових рішень. URL: http://reyestr.court.gov.ua/Review/29620571

14. Цивільний кодекс України: Закон України від 16 січня 2003 р. № 435-IV. Вiдомості Верховної Ради України. 2003. № 40-44. Ст. 356. (Із змінами).

15. Про затвердження Положення про порядок надання в користування земель (земельних ділянок) для потреб Збройних Сил України та основні правила користування наданими 
землями. Наказ Міністра оборони України від 22 грудня 1997 р. № 483. Офічійний веб-портал Верховної Ради Украӥни. URL: https://zakon.rada.gov.ua/rada/show/v0483322-97

16. Про затвердження Порядку відчуження земельних ділянок, на яких розташовані об’єкти нерухомого військового майна, що підлягають реалізації, та земельних ділянок, які вивільняються у процесі реформування Збройних Сил і Державної спеціальної служби транспорту. Постанова Кабінету Міністрів України від 22 травня 2013 р. № 436. Офіиійний вісник України. 2013. № 48. Ст. 1721. (Із змінами).

17. Мірошниченко А. М., Марусенко Р. І. Науково-практичний коментар Земельного кодексу України. К.: Алерта; Центр учбової літератури, 2011. 520 с.

18. Про затвердження переліку видів господарської діяльності, здійснення якої дозволяється військовим частинам: Постанова Кабінету Міністрів України від 25 липня 2000 р. № 1171. Офіціийний вісник України. 2009. № 29. Ст. 973. (Із змінами).

19. Про затвердження Порядку реєстрації військових частин як суб'єктів господарської діяльності у Збройних Силах: Постанова Кабінету Міністрів України від 3 травня 2000 р. № 749. Офіиійний вісник Украӥни. 2000. № 18. Ст. 752. (Із змінами).

20. Про порядок надання дозволу військовим частинам на передачу закріпленого за ними рухомого та не рухомого майна в оренду: Постанова Кабінету Міністрів України від 11 травня 2000 р. № 778. Офіиійний вісник України. 2000. № 20. Ст. 821.

DOI 10.31558/2518-7953.2018.1-2.14

УДК 346.9

А. А. Тварковський

аспірант Донецького національного університету імені Василя Стуса

\section{ЩОДО ПРАВОВОЇ ОСНОВИ ВІДНОВЛЕННЯ ПЛАТОСПРОМОЖНОСТІ АБО ВИЗНАННЯ БАНКРУТОМ ФІЗИЧНОЇ ОСОБИ-ПІДПРИЕМЦЯ}

Ключові слова: фізична особа-підприємечь, банкрутство, відновлення платоспроможності, визнання банкрутом, саначія, розпорядження майном, правова основа.

В умовах ринкової економіки діяльність фізичної особи-підприємця несе для неї низку ризиків та може призвести до неплатоспроможності такого суб'єкта господарювання. У свою чергу для відновлення платоспроможності або визнання банкрутом фізичної особи-підприємця важливу роль відіграє відповідна правова основа.

Правову основу банкрутства фізичної особи-підприємця складають Цивільний кодекс України [1], Господарський кодекс України [2], Закон України «Про 